\title{
Population STRUCTURE of ALNUS JORULLENSIS, A SPECIES USED AS FIREWOOd BY FIVE RURAL COMMUNITIES IN A NATURAL PROTECTED AREA OF MEXICO
}

\section{ESTRUCTURA POBLACIONAL DE ALNUS JORULLENSIS, UNA ESPECIE UTILIZADA COMO LEÑA POR CINCO COMUNIDADES RURALES EN UN ÁREA NATURAL PROTEGIDA DE MÉXICO}

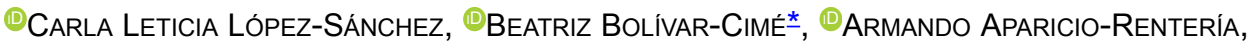 \\ OHÉCTOR VIVEROS-VIVEROS
}

Instituto de Investigaciones Forestales, Universidad Veracruzana, Xalapa, Veracruz, México.

${ }^{*}$ Corresponding author: bolivar_cime@yahoo.com

\begin{abstract}
Background: Ilite (Alnus jorullensis) is a very important pioneer species for the regeneration of temperate forests but also the source of fuel for the inhabitants of the Cofre de Perote National Park in Veracruz, Mexico.

Questions: How much ilite is consumed by families in the Cofre de Perote National Park? What type of population structure is exhibited by Alnus jorullensis? Are there differences in population structure of this species between years? What is the diameter of the individuals extracted for firewood?

Study site and dates: The population structure of ilite was evaluated during April 2016 and April 2017 in five localities of the Cofre de Perote National Park.

Methods: Eighty families in these localities were interviewed about the use of firewood. Eighteen permanent plots of $20 \times 50 \mathrm{~m}$ were established in order to record total height and diameter at breast height $(130 \mathrm{~cm})$ of standing trees of $A$. jorullensis and the basal diameter of its stumps.

Results: Families in the study area indicated that they use in average 2 loads of ilite as firewood per week and extract adult individuals. Population density of ilite decreased from 2016 to 2017, in both years juvenile individuals were predominant, with a low presence of seedlings. Population structure did not differ between years. The basal diameters of stumps measured between 6 and $214 \mathrm{~cm}$.

Conclusions: Extraction of $A$. jorullensis did not change its population structure between years, however local inhabitants perceive that this activity and clandestine logging are affecting their availability.

Keywords: extraction, ilite, recruitment, saplings, seedlings, stumps.

\section{Resumen}

Antecedentes: El Ilite (Alnus jorullensis) es una especie pionera importante para la regeneración de bosques templados y como fuente de combustible para los habitantes del Parque Nacional Cofre de Perote National en Veracruz, Mexico.

Preguntas: ¿Cuánto ilite consumen las familias como leña en el Parque Nacional Cofre de Perote? ¿Qué tipo de estructura poblacional exhibe Alnus jorullensis? ¿Existen diferencias en la estructura poblacional entre años? ¿Cuál es el diámetro de los individuos extraídos para leña?

Sitios y años de estudio: La estructura poblacional del ilite fue evaluada en abril 2016 y abril 2017 en cinco localidades del Parque Nacional Cofre de Perote.

Métodos: Ochenta familias en estas localidades fueron entrevistadas sobre el uso de leña. Dieciocho parcelas permanentes de $20 \times 50 \mathrm{~m}$ fueron establecidas para registrar la altura total y el diámetro a la altura del pecho $(130 \mathrm{~cm})$ de los árboles de $A$. jorullensis en pie y el diámetro basal de los tocones.

Resultados: Las familias entrevistadas dijeron consumir en promedio 2 cargas de ilite por semana y extraer individuos adultos. La densidad de A. jorullensis disminuyó de 2016 a 2017, en ambos años individuos juveniles fueron predominantes con escasa presencia de plántulas. La estructura de la población no difirió entre años. El diámetro basal de los tocones estuvo entre 6 y $214 \mathrm{~cm}$.

Conclusiones: La extracción de Alnus jorullensis no modificó su estructura poblacional entre años. Sin embargo, los habitantes entrevistados perciben que esta actividad junto con la tala clandestina está afectando su disponibilidad.

Palabras clave: extracción, ilite, juveniles, plántulas, reclutamiento, tocones.
\end{abstract}


Forests, the largest climate controllers, are natural habitat to many animals (birds, mammals, reptiles, insects, etc.). They have a great influence on the water cycle and provide wood and several other resources to humans (Chapela 2012). The forest cover in Mexico amounts to $71 \%$ of its territory, including primary and secondary forests (INEGI 2011). However, forests are greatly affected by land use-changes, and the non-sustainable use of resources (Mas et al. 2004).

The non-sustainable extraction of trees for firewood reduces tree biomass and leads to forest degradation (García-Oliva et al. 2014). It affects the regeneration dynamics and population structure of the species subjected to exploitation, especially when the extraction focuses on small-size individuals $(\mathrm{dbh}<10 \mathrm{~cm})$ (Rodríguez-Zúñiga et al. 2011). Forest degradation by extraction of timber products tends to be higher in temperate than in tropical forests, because the exploitation rates exceed by far their regenerating capacity (Torres-Rojo 2004).

In Mexico, natural protected areas (NPAs) were established as a way to maintain the integrity of forest ecosystems and preserve biodiversity, while benefiting from the ecological services they provide (Toledo 2005, YáñezMondragón 2007). However, this is not always the case. In their assessment of the success of NPAs in Mexico from 1993 to 2002, Figueroa \& Sánchez-Cordero (2008) have found that $54 \%$ of NPAs have not been effective in preventing land-use changes and cover depletion. For example, the declaration of the Cofre de Perote National Park (CPNP) in Veracruz, Mexico, as a protected area, targeted not only forest conservation but also the preservation of aquifers that supply drinking water to local communities and beyond (DOF 1937). However, land-use changes to agriculture and grazing (Muñoz-Delfín 2012), as well as the exploitation of forest resources for cooking and heating firewood, has led to serious problems (LópezSánchez 2014).

For the forest area of the Cofre de Perote mountain, the volume of wood extracted (both legally and illegally) has been estimated in $39,626.54 \mathrm{~m}^{3}$ a year, a much smaller amount than the calculated potential of $115,505 \mathrm{~m}^{3}$ a year (Gerez et al. 2012). However, not all timber species are under the same extraction pressure. In the community of El Conejo, within the CPNP, López-Sánchez (2014) interviewed 53 families about the use of firewood including aspects such as collecting sites, tree species used and preferred as firewood, distances traveled to obtain firewood, number of loads ("cargas") of firewood used per week. In this community, a load of firewood is a woodpile with 100 to 120 pieces of wood from trees of different species. According to the interviews the main species used for firewood were: Abies religiosa (Kunth) Schltdl. \& Cham. (oyamel) and Alnus jorullensis Kunth (ilite). Local people say that firewood from these trees is more efficient and lasts longer. Other species of pines used secondarily as firewood were Pinus teocote Cham. \& Schltdl. (ocote), Pinus montezumae Lamb. and Pinus hartwegii Lindl. To estimate the volume of each load, López-Sánchez (2014) used the formula proposed by Gutiérrez et al. (2013) where $\mathrm{V}=$ height $\times$ width $\times$ length of the woodpile $\times$ coefficient that measures the space between pieces of wood. A load of firewood used by nine families in the El Conejo community had a volume from $0.204 \mathrm{~m}^{3}$ to $1.859 \mathrm{~m}^{3}$ (mean $0.504 \mathrm{~m}^{3}$ $\pm 0.517 \mathrm{SD}$ ). Fifty seven percent of the families interviewed indicated that use one load of firewood per week and $30 \%$ two loads.

Although populations of Alnus jorullensis have not yet been surveyed, the little number of standing trees around the communities, the large distances the inhabitants have to travel to find this resource (from 4 to $9 \mathrm{~km}$ ) and their perception that this species becomes scarce in the last 10 years, therefore it could be indicative of the negative impact of wood extraction in the area (López-Sánchez 2014). Other NPAs in Mexico are in a different situation. In the Nevado de Toluca National Park, Mexico State, for example, where A. jorullensis is also extracted, Endara-Agramont et al. (2012) recorded 28 stumps/ha and obtained a J-inverted distribution pattern, according to the diametric categories. The authors concluded that tree removal did not have a negative impact on the species population structure because A. jorullensis was extracted in lesser quantities than Quercus laurina M.Martens \& Galeotti and Abies religiosa (Kunth) Schltdl. \& Cham., although population densities for all three species were similar.

According to Rzedowski (2006), Alnus forests have two ecological characteristics: they thrive along small streams and rivers, and they could form part of successional communities after disturbance. In temperate forests, A. jorullensis, a pioneer species capable of thriving in abandoned fields and other disturbed habitats, is a key factor in soil regeneration process, and therefore an important species for secondary succession (Álvarez-Valle 1956). This long-living species that occupies the canopy (Fredericksen et al. 2001) is specifically associated with species of the genera Pinus, Quercus and Abies (EndaraAgramont et al. 2012) and has been reported as the successive link to Abies religiosa (Nieto de Pascual \& Zamora-Martínez 1989). For these reasons, and for the importance these trees have as fuel for the local inhabitants, it is essential to monitor their natural populations in the Cofre de Perote National Park.

In this study, we interview local inhabitants about the utilization of ilite as firewood and also monitored a population of A. jorullensis trees in April 2016 and April 2017, in order to address the following questions: How much ilite is consumed by families in the Cofre de Perote National Park? What type of population structure does 
Alnus jorullensis exhibit in the Cofre de Perote National Park? Does the population structure vary from one sample year to another? What is the diameter of tree individuals extracted for firewood?

\section{Materials and methods}

Species under study. Alnus jorullensis is a tree of the Betulaceae family, located in mountainous areas with a distribution from Mexico to Argentina, through Central America, the Antilles and several South American countries (Dunn 1987). In the Andes of South America, this species is present in Venezuela, Ecuador, Peru and Argentina (ITTO 2019). In Mexico, its distribution extends from Sinaloa to Chiapas across the Trans Mexican Volcanic Belt (CarranzaGonzález \& Madrigal-Sánchez 1995). It is found in the proximity of bedrock streams and on slopes, at elevations ranging from 2,800 to 3,800 meters above sea level (Furlow 1979). It thrives in deep soils of volcanic origin (andosols), rich in organic matter with a $\mathrm{pH}$ ranging from 4.5 to 6 (Rivera et al. 1998).

Adult trees of Alnus jorullensis can reach more than $20 \mathrm{~m}$ in height, have a rounded canopy, a straight trunk up to 1.8 $\mathrm{m}$ in diameter (DBH) (Carranza-González \& MadrigalSánchez 1995). The species is monoecious, flowering occurs mainly from November to March in Mexico (Carranza-González \& Madrigal-Sánchez 1995) and its pollination is anemophilous. In temperate forests of Mexico, the fruiting has been reported from March to May (CortésFlores et al. 2013), its fruits are dehiscent cones with green coloration at the beginning and brown at maturity (Calderón 2007). On average, each cone contains 80 to 100 seeds which are very small in size $(2 \mathrm{~mm})$, they are winged, flattened with a membranous cover (Calderón 2007) adapted to dispersion by wind (Cortés-Flores et al. 2013). Seeds of A. jorullensis do not have latency (Furlow 1979) and do not form a seed bank in the soil (Díaz-Perea et al. 2014). The germination under controlled conditions occurs between 6 and 29 days, although it may be slower in the field (Nieto \& Rodríguez 2002). Although there is not much information about the seed predation of this species, in Mexico abundant communities of rodents have been found in oak-alder forest presumably due to the large amount of fruits that these species produce (Flores-Peredo \& VázquezDomínguez 2016), in Colombia it has been reported that the rufous-collared sparrow (Zonotricha capensis) consumes its seeds (Jiménez-Rodríguez \& Andrade 2015).

Alnus jorullensis is characterized as a very important species in the regeneration processes of temperate forests (Álvarez-Valle 1956). Due its ability to fix atmospheric nitrogen, it grows in disturbed sites, favoring the establishment of other species (Del Valle-Arango \& González-Pérez 1988). In their superficial roots (the first
$5 \mathrm{~cm}$ of the soil), these trees have nodules through which they maintain a symbiotic relationship with the ascomycete Frankia alni Woronin, which allows it to fix nitrogen (N2) at a rate of approximately $279 \mathrm{~kg} / \mathrm{ha}$ (Calderón 2007).

Alnus jorullensis is associated with woody species such as Pinus, Quercus and Abies (Furlow 1979, EndaraAgramont et al. 2012). Other authors such as Nieto de Pascual \& Zamora-Martínez (1989) have found it to be an important component in the successional transition to Abies religiosa (Oyamel) forest in the Valley of Mexico.

Study area. The study was conducted in the Cofre de Perote National Park (CPNP), Veracruz, located between $19^{\circ} 24^{\prime}$ $08^{\prime \prime}$ and $19^{\circ} 32^{\prime} 04^{\prime \prime} \mathrm{N}$, and $97^{\circ} 05^{\prime} 07^{\prime \prime}$ and $97^{\circ} 12^{\prime} 05^{\prime \prime}$ W (Vázquez-Ramírez 2014). Until 2012, the Park's area $(11,550 \mathrm{ha})$ was occupied mainly by forest (48.3\%), followed by agricultural lands (32\%), grasslands (19\%) and human settlements (0.7\%) (Muñoz-Delfín 2012).

According to the Köppen classification modified by García (1981), the dominant climate, over an area of 6,113 ha, is semi-cold sub-humid with long fresh summers $\mathrm{Cb}^{\prime}(\mathrm{w} 2)$, with total precipitation of 1,000 to $1,200 \mathrm{~mm}$; followed by a semi-cold humid climate with long fresh summers $\mathrm{Cb}^{\prime}(\mathrm{m})(\mathrm{f})$ with total rainfall of 1,500 to $1,800 \mathrm{~mm}$, over an area of 5,338 ha, (CONANP 2012).

Field data. Five communities were selected within the CPNP where it is known that there is a large use of firewood to carry out their daily activities (cooking, bathing, heating the house) and where it is also possible to find patches of vegetation with Alnus jorullensis, these were: Los Pescados, El Conejo, Escobillo, Rancho Nuevo and Colonia Agricola. We applied a semi-structured interview to 20 families from each locality (except the Colonia Agricola), in order to get the information on the consumption of $A$. jorullensis as firewood, due to previous study conducted by López-Sánchez (2014) only reported information about Los Pescados.

The population structure was evaluated in April 2016 and April 2017. A convenience non-probabilistic sampling was carried out, since the plots were established in the five communities seeking remnants of forest that presented individuals from Alnus jorullensis, these were located near roads and highways to facilitate access. Eighteen permanent plots of $20 \times 50 \mathrm{~m}(1.8 \mathrm{ha})$ were established at an altitude of 3,200 to $3,422 \mathrm{~m}$ asl. in forest and some agricultural lands with patches of Alnus trees and were separated at least $50 \mathrm{~m}$ (Figure 1), the minimum distance from the plots to human settlements was $318 \mathrm{~m}$ and the maximum distance was $1,686 \mathrm{~m}$. All the individuals of the species were recorded within each plot, for each tree total height was measured with an electronic clinometer (ECII Haglöf ${ }^{\circledR}$ ), and the diameter at breast height (dbh) was measured with a 


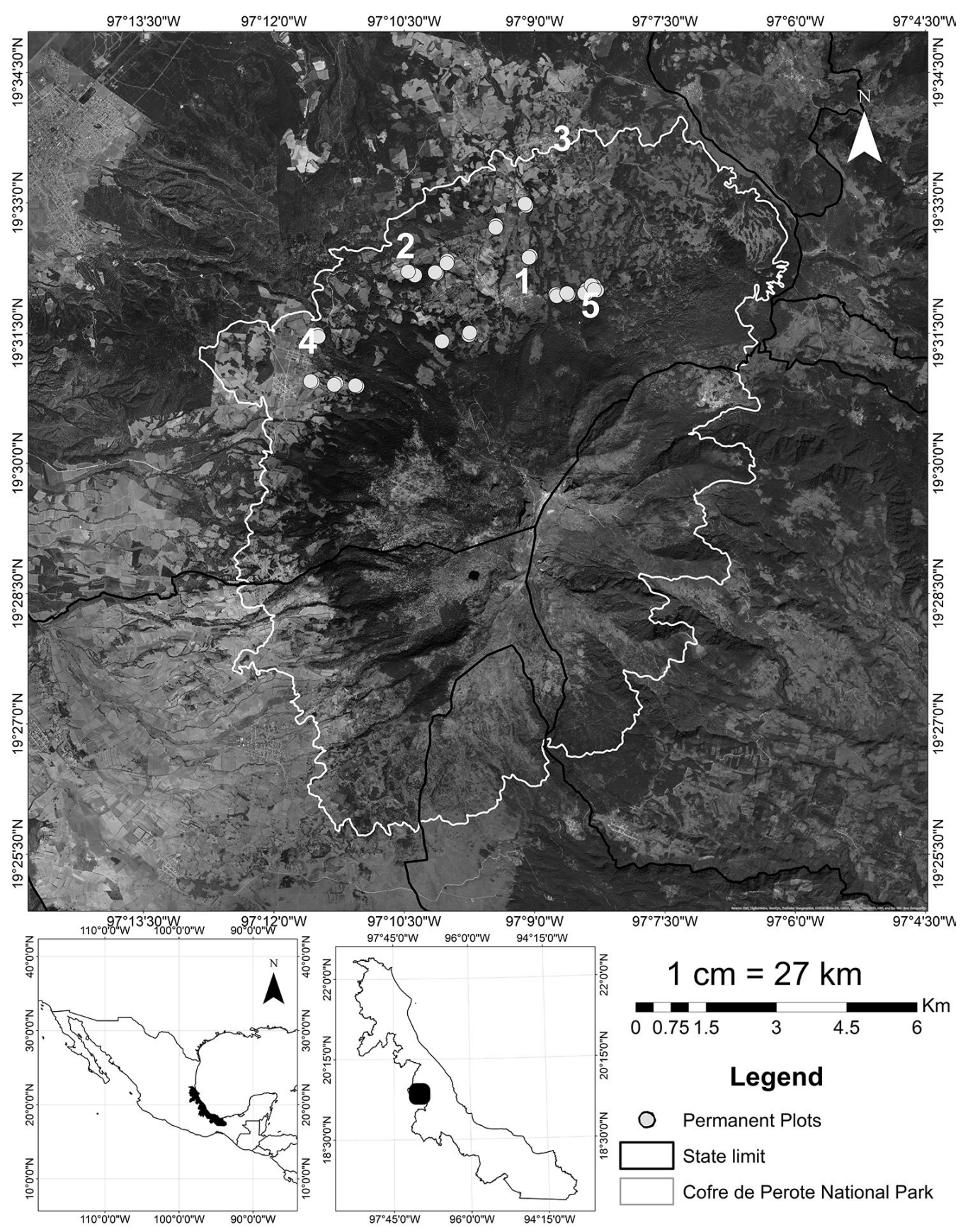

Figure 1. Location of the permanent plots (circles) to assess the population structure of Alnus jorullensis in the Cofre de Perote National Park, Mexico. Localities: 1. El Conejo, 2. El Escobillo, 3. Los Pescados, 4. Rancho Nuevo, 5. Colonia Agrícola.

diametric tape (Forestry Suppliers ${ }^{\circledR}$ ). The number of stumps and their basal diameter (bd) were also recorded at each plot (Valdez-Hernández 2002).

Other plant species recorded within the permanent plots were woody trees (Abies religiosa, Pinus montezumae Lamb), shrubs (Acaena elongata L., Barkleyanthus salisifolius (Kunth) H.Rob. \& Brettell, Baccharis conferta Kunth) and grass (Muhlenbergia macroura Hitchc.).
Individual categorization. Recorded individuals were classified according to their height: seedlings $\leq 50 \mathrm{~cm}$ high, saplings $>50 \mathrm{~cm}$ and $<130 \mathrm{~cm}$ high. Those Individuals whose diameter at breast height ( $\mathrm{dbh}$ ) could be measured at $130 \mathrm{~cm}$ were classified in categories at $10-\mathrm{cm}$ intervals. The Weibull density probability function was applied to describe the distribution of absolute frequencies of the diametric categories considered. The Weibull distribution parameters 
$a, b$ and $c$ (position, scale and shape, respectively) were estimated using the standard Minitab 19 procedure for the identification of the individual distribution.

For furcated individuals, the dbh of all stems were measured and weighted with the following formula, proposed by Gouwakinnou et al. (2009):

$$
d p=\left(\sum_{i=1}^{y} d_{i}^{2}\right)^{1 / 2}
$$

Where; $d p$ is the weighted dbh (hereafter referred to as $\mathrm{dbh}), d_{i}$ is the dbh for each stem.

The stumps density per hectare was calculated for each period. Finally, for the purpose of determining whether there was a preference in the size of the extracted trees, stumps were grouped into categories according to their basal diameter (bd) at 20-cm intervals.

Statistical analysis. A Wilcoxon test was performed to assess differences in the number of individuals in the height and dbh categories between 2016 and 2017. This test was also applied to compare the number of stumps recorded in bd categories each year, as a measure of tree extraction. Since tree extraction was found to be significantly different from one year to another, it was decided to carry out another Wilcoxon test to compare the population structure of A. jorullensis considering only the categories of trees that were extracted the most (i.e., saplings and individuals with dbh between $0.1 \mathrm{~cm}$ and $40 \mathrm{~cm}$ ).

\section{Results}

According to the interviews, each family in the four locations consumes on average $2 \pm 1.8$ SD loads of illite per week. Eighty eight percent of the families interviewed mentioned using adult Alnus trees as firewood, of these $50 \%$ indicated using fallen trees, $40 \%$ used dry trees and $30 \%$ sick trees, it is important to emphasize that families could simultaneously consume both fallen and standing trees but with some problem (dry and/or sick from pests). The remaining $12 \%$ of families said they use all kinds of trees from small to adults. About the sites for collect firewood, $52 \%$ of the families interviewed mentioned that they obtain it from the forest, $39 \%$ obtain it from private or abandoned agricultural lands, $5 \%$ from logging lands and 4 $\%$ bought it.

In 2016, the population density of $A$. jorullensis was 256 individuals/ha, and 38 stumps/ha (mean bd: $36.37 \mathrm{~cm}$, maximum bd: $214 \mathrm{~cm}$, minimum bd: $6 \mathrm{~cm}$ ) were recorded. Of the total of 69 stumps registered, 56 showed regrowth. Taking height as a measure, a scarce 36 seedlings were found $(7.7 \%$ of the total population studied) and 176 saplings (38\%). As for diametric categories, $34.8 \%$ of the individuals were grouped in categories from 10 to $40 \mathrm{~cm}$ (Figure 2). As the stumps revealed, the most exploited trees were found to have a basal diameter of between 6 and 40 $\mathrm{cm}$ (Figure 3).

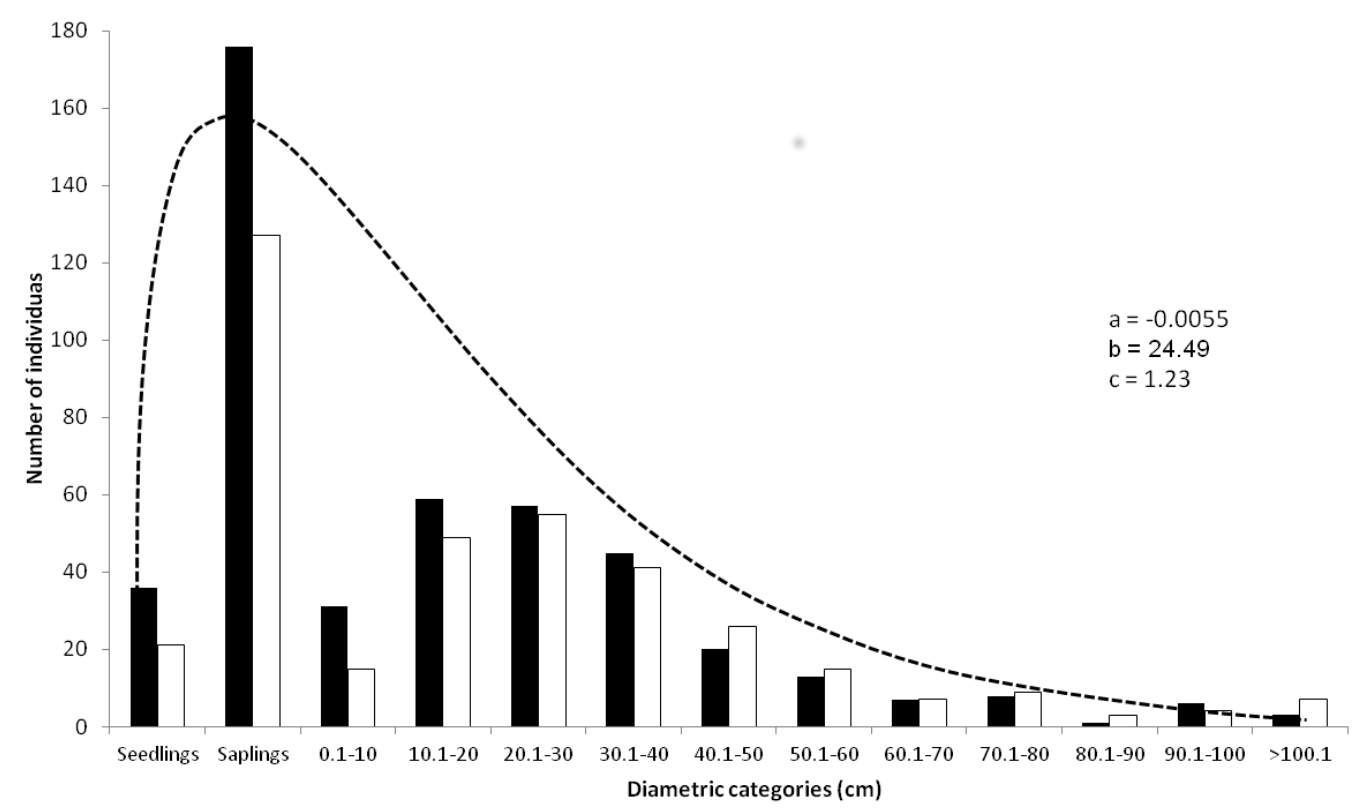

Figure 2. Population structure of Alnus jorullensis in the Cofre de Perote National Park, Mexico. April 2016 (black bars) and April 2017 (white bars) and Weibull probability distribution adjustment (dashed line). 


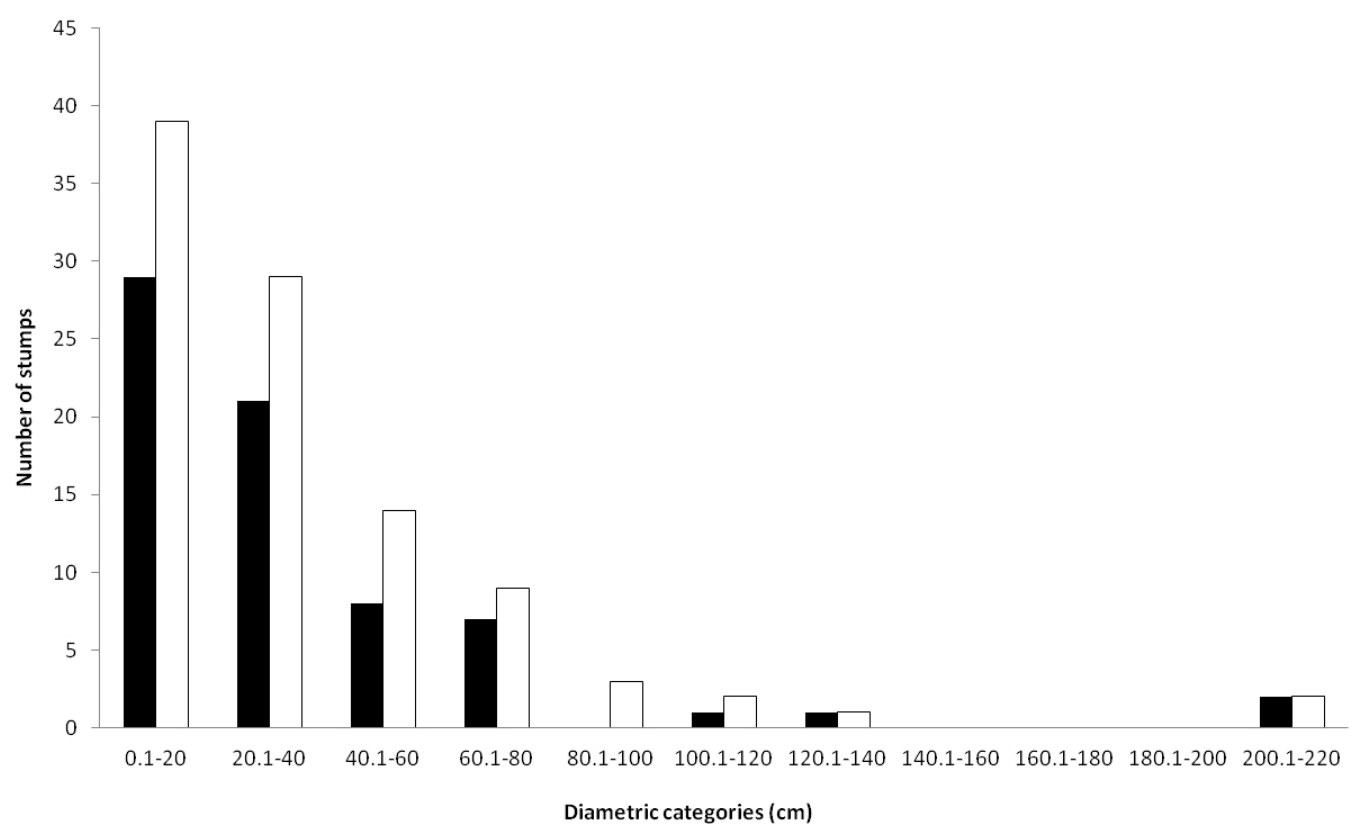

Figure 3. Size structure of Alnus jorullensis stumps in the Cofre de Perote National Park, Mexico. April 2016 (black bars) and April 2017 (white bars).

In 2017, the population density of A. jorullensis was 210 individuals/ha. In terms of tree extraction, a density of 55 stumps/ha was recorded with a mean basal diameter of $37.43 \mathrm{~cm}$ (maximum and minimum bd were the same as the previous year). The most exploited trees were found to have a basal diameter between 6 and $40 \mathrm{~cm}$; and 89 of the totals of 99 stumps registered showed regrowth. Twenty-one seedlings $(5.5 \%)$ and 127 saplings $(33 \%)$ were recorded, slightly less than was reported in 2016 . Similarly, $38.4 \%$ of the individuals were found with a dbh between 10 and 40 $\mathrm{cm}$ (igure 2, 3).

Statistical analyses showed no significant difference $(V=55.5, p=0.20)$ in the population structure of A. jorullensis between April 2016 and April 2017. However, in terms of the extraction for firewood, a significant difference was found in the number of stumps registered in the two periods $(V=0.001, p=0.03$ ).

Considering only the categories of the most extracted trees (6-40 $\mathrm{cm}$ bd of stumps), significant differences were found in the number of individuals belonging in these categories in the two periods $(V=21, p=0.03)$.

\section{Discussion}

Considering the information obtained from 80 families interviewed in the study area, in overage 2 loads of ilite are consumed by family per week as firewood. May be this amount could be overestimated by people because they collect firewood according to its availability in field, during their weekly journey, then it is difficult separate the loads of firewood by species to estimate utilization rates. A previously study in Los Pescados conducted by LópezSánchez (2014) found that volume of a load could vary between families due the size of the woodpile and the tree species that form it, however $57 \%$ of the families indicated consume one load of firewood (from different species) per week. Therefore, the amount of ilite consumed by these families could be lesser than they indicated. Although most of the families interviewed indicated that use fallen trees of Alnus as firewood, in field some people deliberately causes damage to standing trees that cause them to fall or dry (obs. pers. López-Sánchez), in fact some plots presented trunks with ax marks. In this study extraction of A. jorullensis did not change its population structure between years, but local inhabitants perceive that this activity and clandestine logging are affecting their availability near to their communities.

The population structure of $A$. jorullensis did not show a J-inverted tendency in either period. This tendency is characterized by the predominance of individuals at the early stages of development (seedlings and saplings), which makes a population stable and self- regenerative, and ensures its long-term maintenance (Puettmann et al. 2016). In the natural protected area of the CPNP, Alnus populations did not show a significant recruitment of new individuals. In the sampled area of 1.8 ha, only 36 seedlings were 
recorded in 2016, and 21 in 2017. The number of saplings (176) represented $38 \%$ of the population in 2016 and decreased to $33 \%$ (127 individuals) in 2017. In terms of the diametric categories, the recorded population structure was similar to the one expected, where the number of individuals decreased with the increase in dbh size (Puettmann et al. 2016).

These results differ from those obtained in other NPAs of Mexico. For example, Rojas-García \& Villers-Ruíz (2008) in the Malinche National Park, and Endara-Agramont et al. $\underline{(2012)}$ in the Nevado de Toluca National Park, reported that populations showed a J-inverted trend. However, the former study was based only on diametric categories, in exclusion of seedlings recruitment. In the latter study, though the presence of seedlings was assessed (individuals with height $<30 \mathrm{~cm}$ ), records for this category were not obtained, and the presence of a large number of juveniles (approximately $30 \%$ of total individuals) was registered. This value is similar to the one recorded in the present study, where juveniles (saplings) represented more than $30 \%$ of the total individuals in the two periods evaluated.

Several factors of anthropic or natural origin could be negatively influencing the natural regeneration of Alnus jorullensis. Hernández-Vargas et al. (2000), and OlveraVargas et al. (2014) did not record natural regeneration of $A$. jorullensis under the influence of grazing, but reported the presence of four saplings in a pine-oak forest, as well as 25 saplings/ha and 26 adults/ha in areas with light and moderate grazing, respectively. This suggests that this species is affected by the presence of herbivores. An eightyear monitoring study in a subtropical forest dominated by Quercus in secondary succession recorded a very low recruitment rate for this species $(0.31 \%)$, especially in areas with high tree density (e.g., 85-90 individuals per plot) (Olvera-Vargas et al. 2015). Since a higher density of individuals promotes a more closed canopy, this could be avoiding the germination of shade-intolerant $A$. jorullensis (Díaz-Perea et al. 2014).

This species is also characterized by the ability to regrowth, which was reflected in the present study, where $89 \%$ of the stumps registered (99) showed regrowth. It has been suggested that this characteristic represents a plantregeneration mechanism which increases persistence under critical environmental conditions, as occurs in severely disturbed sites (Díaz-Perea et al. 2014). Furthermore, resprouters almost always have fewer seedlings and poorer seedling survival than nonsprouters (Bond \& Midgley 2001). This characteristic could explain the low natural regeneration recorded in the study area, it also could be influenced by the moment when monitoring was carried out during the middle of the fruiting period (April, CortésFlores et al. 2013), registering only the first germination stage of each year. However, under controlled conditions the percentages of germination obtained from seeds collected in 2016 were less than $25 \%$ (López-Sánchez et al. 2018), this percentage that could be much lower under natural conditions as reflect our data. Furthermore, the Alnus jorullensis biology has shown that it does not form seed banks, which may also influence its population dynamics (Díaz-Perea et al. 2014).

Nevertheless, a better natural regeneration for A. jorullensis has been found in other NPAs of Veracruz, Mexico. In San Juan del Monte, Rodríguez et al. (2016) have reported a maximum of 100 seedlings/ha (18 ha sampled) in areas under different forestry treatments. The better recruitment of this species in the area may be a function of the correct application of these treatments, whose aim was to modify forest population structure as a way to ensure regeneration through time (Manzanero \& Pinelo 2004).

Although the population structure of Alnus jorullensis did not change from one sample year to another, significant differences were found in the number of individuals most frequently extracted for firewood, as revealed by the information obtained from the stumps and the established diametric categories.

A density of 38 stumps/ha was found in 2016, and 55 stumps/ha in 2017, and the extraction focused on individuals with a basal diameter of 6 to $40 \mathrm{~cm}$. More than $80 \%$ of the families interviewed in the study area said that they use adult Alnus trees, these could be represented by individuals in the $10-40 \mathrm{~cm}$ diameter categories that were highly frequent in the population structure. Similar results were recorded by Endara-Agramont et al. (2012b) in the Nevado de Toluca, were the extraction focused on individuals with a basal diameter of 5 to $30 \mathrm{~cm}$. EndaraAgramont et al. (2012) found a density of 28 stumps/ha, smaller than the one found in this work. This may be due to the low demand for firewood from this species in the Nevado de Toluca, where the most exploited species is Quercus laurina, with 314 stumps/ha.

In temperate forests in the study area, it has been estimated that up to four loads of firewood can be obtained from a tree with $\mathrm{dbh}$ around $50 \mathrm{~cm}$ (1 load equals approximately $70 \mathrm{~kg}$ ), and that 29 trees of similar dimensions per year would be required to satisfy the firewood needs of a family (Gerez et al. 2012). According to INEGI (2000), in four of the five locations where Alnus populations were monitored, more than $90 \%$ of inhabited households used firewood as fuel. It is very likely that these values have not changed 17 years later, due to the rise in butane gas prices. As observed during this study (pers. obs. López-Sánchez) and indicated by recent studies (Gerez et al. 2012), butane gas has become inaccessible for most local inhabitants. This high demand for firewood could explain the decrease in the density of trees of this species from one 
sample year to another, and especially the reduction in the number of individuals in the most used categories. This problem was perceived by $70 \%$ of the families interviewed in the study area, since they mentioned that the extraction of firewood and clandestine logging are damaging their forests becoming this resource scarcer.

Alnus jorullensis densities vary greatly, which may be explained by the characteristics and history of each site, as well as the human impact. In the Valley of Mexico, an average density of $40 \mathrm{~A}$. jorullensis individuals/ha has been reported in association with Pinus montezumae (Nieto de Pascual \& Zamora-Martínez 1989), whereas in the Malinche National Park 207 individuals/ha of this species were reported in association with $P$. montezumae (RojasGarcía \& Villers Ruiz 2008). Conversely, in the Nevado de Toluca National Park, 572 individuals/ha were found in areas where this species replaced pine and oak forests, impacted by fire and other human activities (EndaraAgramont et al. 2012). In this study, 256 individuals/ha were recorded in 2016 and 210 individuals/ha in 2017, with a marked density-decrease trend. Even if the population of A. jorullensis was monitored only in five communities within CPNP, other areas in the park with similar amounts of extraction and low regeneration of this species could have had the same trend but this must be explored in further studies.

Although Alnus jorullensis has not been considered to be particularly vulnerable to disturbance (Díaz-Perea et al. 2014), human activities have had a strong impact on the population dynamics of $A$. jorullensis in the five communities studied in the CPNP. The direct extraction of adults and juvenile individuals, the most readily available exemplars ( $>30 \%$ of the total population), thwarts their transition to adulthood, and consequently slows natural regeneration.

The extraction of $A$. jorullensis was present in the five communities included in this study, which accounts for the utilitarian importance of this species for the local communities. Isolated Alnus individuals were found in areas of difficult access, but they did not form new forest patches (pers. obs. López-Sánchez) or were present in agricultural lands (private) where owners left some individuals as firewood source. Similar observations have been reported in other studies that evaluate the effect of tree extraction on the structure and composition of temperate forests, where individuals of Alnus jorullensis (used for firewood or for the construction of fences) were restricted to ravines or sites of difficult access (Estrada-Valdés 2018). In the absence of adequate forest planning, and with no more trees to provide seeds, it can be expected that this species will soon disappear from the temperate forest community (EstradaValdés 2018).
Although the current status of $A$. jorullensis populations throughout the CPNP is unknown, this study conducted in five communities reflects the need for further multidisciplinary studies to evaluate the populations of the most used species as firewood in this natural protected area, as a way to ensure a balance between forest conservation and people welfare.

\section{Acknowledgements}

The authors would like to thank the Consejo Nacional de Ciencia y Tecnología (CONACYT) Mexico, for the master scholarship granted to the first author (No. 592689). We also thank two anonymous readers whose observations helped us improve the manuscript.

\section{Literature cited}

Álvarez-Valle H. 1956. Estudio forestal del Jaúl (Alnus jorullensis $H B K$ ) en Costa Rica. MSc. Thesis, Instituto Interamericano de Ciencias Agrícolas, Costa Rica.

Bond WJ, Midgley JJ. 2001. Ecology of sprouting in woody plants: the persistence niche. Trends in Ecology and Evolution 16: 45-51 DOI: https://doi.org/10.1016/ s0169-5347(00)02033-4

Calderón M. 2007. Extracción y caracterización fisicoquímica del extracto colorante de la corteza de Aliso común (Alnus jorullensis Humboldt, Bonpland \& Kunth), proveniente de San Lucas Sacatepéquez Guatemala. MSc. Thesis, Universidad de San Carlos, Guatemala.

Carranza-González E, Madrigal-Sánchez X. 1995. Betulaceae. Flora del Bajío y de regiones adyacentes Fascículo 39: 1-22.

Chapela F. 2012. Estado de los bosques en México. México. Consejo Civil Mexicano para la Silvicultura Sostenible AC. https://www.ccmss.org.mx/acervo/estado-de-losbosques-de-mexico/ (accessed November 17, 2018).

CONANP [Comisión Nacional de Áreas Naturales Protegidas] 2012. Programa de manejo del Parque Nacional Cofre de Perote. https://www.gob.mx/conanp/ acciones-y-programas/programas-de-manejo (accessed January 18, 2018).

Cortés-Flores J, Andresen E, Cornejo-Tenorio G, IbarraManríquez G. 2013. Fruiting phenology of seed dispersal syndromes in a Mexican Neotropical temperate forest. Forest Ecology and Management 289: 445-454. DOI: https://doi.org/10.1016/j.foreco.2012.10.038

Del Valle-Arango J, González-Pérez H. 1988. Rendimiento y crecimiento del cerezo (Alnus jorullensis) en la región central andina, Colombia. Revista Facultad Nacional de Agronomía Medellín 41: 61-91. 
DOF [Diario Oficial de la Federación]. 1937. Decreto Presidencial que declara Parque Nacional la montaña Cofre de Perote o Nauhcampatépetl, en el Estado de Veracruz, México. https://www.dof.gob.mx/nota detalle. php?codigo $=5379137 \&$ fecha $=21 / 01 / 2015 \quad$ (accessed January 15, 2018).

Díaz-Perea F, Equihua M, Jaramillo V, Méndez-Ramírez I, Fragoso C. 2014. Key attributes to the disturbance response of montane cloud forest trees: shade tolerance, dispersal mode and the capacity to form a seed bank. Annals of Forest Science 71: 437-451. DOI: https:// doi.org/10.1007/s13595-014-0357-5

Dunn WW. 1987. A fuelwood management plan and costbenefit analysis for alder (Alnus jorullensis) in the Ecuadorian Andes. MSc. Thesis. The University of Arizona.

Endara-Agramont AR, Franco-Maass S, Nava-Bernal G, Valdez-Hernández J, Fredericksen T. 2012. Effect of human disturbance on the structure and regeneration of forests in the Nevado de Toluca National Park, Mexico. Journal of Forest Research 23: 39-44. DOI: https:// doi.org/10.1007/s11676-012-0226-8

Endara-Agramont AR, Nava-Bernal G, Franco-Maass S, Espinoza-Maya A, Ordóñez-Díaz JAB, Mallén-Rivera C. 2012b. Extracción de madera en el Parque Nacional Nevado de Toluca. Revista Mexicana de Ciencias Forestales 3: 81-90.

Estrada-Valdés G. 2018. Efecto del aprovechamiento forestal sobre la estructura y composición de un bosque templado del estado de México. MSc. Thesis. Universidad Autónoma del Estado de México.

Flores-Peredo R, Vázquez-Domínguez G. 2016. Influence of vegetation type and season on rodent assemblage in a Mexican temperate forest mosaic. Therya 7: 357-369. DOI: https://doi.org/10.12933/therya-16-390

Fredericksen T, Contreras F, Pariona W. 2001. Guía de Silvicultura para Bosques Tropicales de Bolivia. Santa Cruz, Bolivia: Proyecto de Manejo Forestal Sostenible BOLFOR.

Figueroa F, Sánchez-Cordero V. 2008. Effectiveness of natural protected areas to prevent land use and land cover change in Mexico. Biodiversity and Conservation 17: 3223-3240. DOI: https://doi.org/10.1007/s10531008-9423-3

Furlow J. 1979. The Systematics of the American Species of Alnus (Betulaceae). Rhodora 81: 151-284.

García E. 1981. Modificaciones al sistema de clasificación climática de Koppen. Para adaptarlo a las condiciones de la República Mexicana. México, DF: Instituto de Geografía, Universidad Nacional Autónoma de México.

García-Oliva F, Covaleda S, Gallardo J, Prat C, VelázquezDurán R, Etchevers J. 2014. Firewood extraction affects carbon pools and nutrients in remnant fragments of temperate forests at the Mexican Transvolcanic Belt. Bosque 35: 311-324. DOI: http://dx.doi.org/10.4067/ S0717-92002014000300006

Gerez P, Fuentes T, Vidriales-Chan G, Toledo-Aceves T, Pérez K. 2012. Características sociales y problemática de la subcuenca. In: Paré L, Gerez P, coords. Al filo del agua: cogestión de la subcuenca del río Pixquiac, Veracruz. México: Universidad Nacional Autónoma de México /Sendas, AC/Universidad Veracruzana/Secretaría del Medio ambiente y Recursos Naturales/Instituto Nacional de Ecología/Universidad Iberoamericana, Campus Puebla, Juan Pablos Editores, pp. 135-190. ISBN: 978-607-7908-89-0

Gouwakinnou GN, Kindomihou V, Assogbadjo AE, Sinsin B. 2009. Population structure and abundance of Sclerocarya birrea (A. Rich) Hochst subsp. birrea in two contrasting land-use systems in Benin. International Journal of Biodiversity and Conservation 1: 194-201. DOI: https://doi.org/10.5897/IJBC

Gutiérrez E, Moreno R, Villota N. 2013. Guía de cubicación de madera. Colombia: Gobernanza Forestal y Unión Europea. ISBN: 978-958-8370-42-2

Hernández-Vargas G, Sánchez-Velásquez LR, CarmonaValdovinos TF, Pineda-López MR, Cuevas-Guzmán R. 2000. Efecto de la ganadería extensiva sobre la regeneración arbórea de los bosques de la Sierra de Manantlán. Madera y Bosques 6: 13-28. https://doi.org/ $\underline{10.21829 / \mathrm{myb} .2000 .621332}$

INEGI [Instituto Nacional de Estadística y Geografía] 2000. XII Censo General de Población y Vivienda 2000. https://www.inegi.org.mx/programas/ccpv/2000/ (accessed September 30, 2019).

INEGI [Instituto Nacional de Estadística y Geografía]. 2011. Carta de uso de suelo y vegetación, Serie V (2011), escala 1:250 000. In: Instituto Nacional de Estadística y Geografía, México.

ITTO 2019. http://www.tropicaltimber.info/es/specie/alisoAlnus-jorullensis/ (accessed October 4, 2019).

Jiménez-Rodríguez L, Andrade SV. 2015. Caracterización de las cercas vivas y la avifauna asociada en la vereda San Felipe, microcuenca Mijitayo, municipio De Pasto, departamento de Nariño. BSc. Thesis. Universidad de Nariño.

López-Sánchez C. 2014. Uso de leña y estufas ahorradoras en la comunidad El Conejo, Municipio de Perote, Veracruz. BSc. Thesis, Universidad Veracruzana, México.

López-Sánchez C, Bolívar-Cimé B, Viveros-Viveros H, Aparicio-Rentería A. 2018. Evaluación de la propagación de Alnus jorullensis Kunth de un Área Natural Protegida de México. Avances en investigación agricola, pecuaria, forestal, acuicola, pesquera, desarrollo rural, transferencia de tecnología, 
biotecnología, ambiente, recursos naturales y cambio climático 2: 917-926.

Manzanero M, Pinelo G. 2004. Plan silvicultural en unidades de manejo forestal. WWF Centroamericana. San Francisco de Dos Ríos, Costa Rica.

Mas JF, Velázquez A, Díaz-Gallegos JR, Mayorga-Saucedo R, Alcántara C, Bocco G, Castro R, Fernández T, PérezVega A. 2004. Assessing land use/cover changes: a nationwide multidate spatial database for Mexico. International Journal of Applied Earth Observation and Geoinformation 5: 249-261. DOI: https://doi.org/10. 1016/j.jag.2004.06.002

Muñoz-Delfín H. 2012. Tasa de transformación del hábitat del Parque Nacional Cofre de Perote. Comisión Nacional De Áreas Naturales Protegidas. https:// $\underline{\text { simec.conanp.gob.mx/pdf_evaluacion/perote.pdf }}$ (accessed December 10, 2018).

Nieto VM, Rodríguez J. 2002. Alnus jorullensis. In: Vozzo JA, ed. Tropical tree seed manual. Washington DC: USDA Forest Service, pp. 292-293.

Nieto de Pascual C, Zamora-Martínez M. 1989. Características del Aile (Alnus jorullensis HBK ssp. jorullensis). Revista Ciencia Forestal 14: 99-114.

Olvera-Vargas M, Figueroa-Rangel B, Cuevas-Guzmán R. 2014. Environmental filters and patterns of tree regeneration in high altitude sub-tropical Quercusdominated forests. Ecological Research 29: 711-721. DOI: https://doi.org/10.1007/s11284-014-1163-0

Olvera-Vargas M, Figueroa-Rangel BL, Vázquez-López JM. 2015. Tree mortality and recruitment in heterogeneous stands of sub-tropical mixed-oak forests in west-central Mexico. Interciencia 40: 233-240.

Puettmann KJ, Messier C, Coates KD. 2016. Crítica de la silvicultura: el manejo para la complejidad. España: Asoc. Cultural y Científica Iberoamérica. ISBN-10: 8416549230

Rivera H, Vega E, Herrera G. 1998. Guía para plantaciones forestales comerciales Nariño. Bogotá, Colombia. Corporación Nacional de Investigación y Fomento Forestal. 36: 1-39.

\footnotetext{
Associated Editor: Numa Pavón

Author contributions: CLLS conceived the idea, analysed the data, wrote the paper and reviewed drafts of the paper. BBC discussed the idea, designed and performed the sampling, analysed the data, wrote the paper and reviewed drafts of the paper. AAR discussed the idea, participated in the sampling design and reviewed drafts of the paper. HVV discussed the idea, participated in the sampling design and reviewed drafts of the paper.
}

Rodríguez D, Acosta C, Linares $\mathrm{P}$, Suárez A, Jiménez J. 2016. Condición del bosque de coníferas de la Reserva de San Juan del Monte, Veracruz, post-aprovechamiento forestal. In: Narave-Flores HV, Garibay-Prado L, Chamorro-Zarate MÁ, Álvarez-Oseguera LR, De la Cruz-Elizondo Y. eds. El Cofre de Perote Situación, Perspectivas e Importancia. Universidad Veracruzana, Xalapa, Veracruz, México, pp. 173-177.

Rodríguez-Zúñiga MT, Ramírez-García P, GutiérrezGranados G. 2011. Efectos de la extracción no controlada de madera sobre la comunidad y estructura de tamaños de los manglares de Alvarado, Veracruz, México. Boletín de la Sociedad Botánica de México 89: 107-113. DOI: https://doi.org/10.17129/botsci.371

Rojas-García F, Villers-Ruíz L. 2008. Estimación de la biomasa Forestal del Parque Nacional Malinche: Tlaxcala-Puebla. Revista Ciencia Forestal en México 33: 59-86.

Rzedowski J. 2006. Vegetación de México. $1^{\text {a }}$ edición digital. México: Comisión Nacional para el Conocimiento y Uso de la Biodiversidad.

Toledo V. 2005. Repensar la conservación: ¿Áreas naturales protegidas o estrategia bioregional? Gaceta Ecológica. 77: $67-83$

Torres-Rojo J. 2004. Estudio de tendencias y perspectivas del sector forestal en América Latina. Secretaría de Medio Ambiente y Recursos Naturales de México, y Organización de las Naciones Unidas para la Agricultura y la Alimentación. $105 \mathrm{p}$.

Valdez-Hernández JI. 2002. Aprovechamiento forestal de manglares en el estado de Nayarit, Costa Pacífica de México. Madera y Bosques 8: 129-145. DOI: https:// doi.org/10.21829/myb.2002.801296

Vázquez-Ramírez J. 2014. Fenología reproductiva de las comunidades vegetales del Parque Nacional Cofre de Perote, Veracruz, México. MSc. Thesis, Universidad Veracruzana, México.

Yáñez-Mondragón C. 2007. Las Áreas Naturales Protegidas en México, criterios para su determinación. Caso de estudio: Sierra Tarahumara, Estado de Chihuahua. S. Thesis, Academia de Ingeniería México. 